\title{
Development of an L-Lysine Enriched Bran for Animal Nutrition via Submerged Fermentation by Corynebacterium glutamicum using Agroindustrial Substrates
}

\author{
Luiz Alberto Letti Junior ${ }^{\mathbf{1}}$, Gilberto Vinícius Melo Letti ${ }^{\mathbf{1}}$, Carlos Ricardo Soccol ${ }^{\mathbf{1}}$. \\ ${ }^{I}$ Universidade Federal do Paraná, Departamento de Engenharia de Bioprocessos e Biotecnologia, Curitiba, Paraná, \\ Brasil.
}

\begin{abstract}
L-Lysine is an essential aminoacid added as supplement for animal feed. The aim of this work was to produce an LLysine enriched bran using Brazilian agroindustrial byproducts. Both the raw material costs and purification steps were minimized. Firstly, medium composition for the growth of Corynebacterium glutamicum ATCC 21799 was optimized targeting enhanced L-Lysine production - salt, vitamins and nitrogen sources concentrations were tested and selected. Next, UV mutant strains were generated and the best producers were used in formulated media using sugarcane molasses. It was reached a production of $9.3 \mathrm{~g} / \mathrm{L}$ of L-Lysine with the optimized formulated media. This $L$ Lyisne rich broth was then impregnated and cyclically reimpregnated in pre-treated solid matrixes (sugarcane bagasse, citrus pulp, brewer spent grain, soybean husk and wheat bran). After processing, it was generated enriched brans with significant amounts of L-Lysine (13.8\%, 7.0\%, 8.9\%, 5.9\% and 8.4\%, respectively), which has an interesting market potential for animal feed.
\end{abstract}

Key words: L-Lysine, Corynebacterium glutamicum, submerged fermentation, animal nutrition, enriched bran

\section{INTRODUCTION}

Aminoacids are the building blocks of proteins. Some aminoacids are synthesized naturally by the animals via their metabolism while others must be obtained through nutrition, known as essential aminoacids. Considering the growth of pigs and chickens, some of the essential aminoacids are present in sufficient amounts in grains like wheat and corn, while for other, supplemental external sources are required. It is the case of L-Lysine, which is usually recognized as the primary limiting aminoacid in various grains and oleaginous species (Shah et al. 2002). Due to this reason, L-Lysine is one of the most important aminoacids used as supplement in animal feed. In 2015, the world market for L-Lysine was around 2.2 million tons per year (Eggeling and Bott, 2015).

L-Lysine is produced mainly via submerged fermentation, which represents around $80 \%$ of worldwide market. Corynebacterium glutamicum or engineered Escherichia coli are employed to carry out the fermentation steps (Coello et al. 2002). The major costs involved in L-Lysine production are due to raw material followed by separation and purification steps (Whitmann and Becker 2007). The final product is usually presented as a salt, Lysine- $\mathrm{HCl}$ (Lysine monochloridrate) (Anastassiadis 2007). However, it can also be presented as L-Lysine liquid formulations or in granulated form. The last form is interesting from

\footnotetext{
*Authors for correspondence: letti@ufpr.br
} 
the economical point of view, since less purification steps are required (Kelle et al. 2005).

The aim of this work was to produce an L-Lysine enriched bran using Brazilian agroindustrial byproducts. The first part of the work involved the medium optimization for the growth of Corynebacterium glutamicum ATCC 21799, followed by generation of mutants with enhanced L-lysine production and selection of suitable and low cost raw materials for fermentation. The subsequent steps were related to the preparation (drying, milling, classification) of agroindustrial residues, which were used as matrixes to receive the fermentation broth rich in L-Lysine. The final steps involved cycles of reimpregnation of the matrixes with the fermented broth and drying of the product to generate the L-Lysine enriched solid bran.

\section{MATERIALS AND METHODS}

\section{Microrganisms}

Corynebacterium glutamicum ATCC 21799 was used in this work. The strain was received in lyophilized form and stored at $-20{ }^{\circ} \mathrm{C}$. The reactivation was performed using Nutrient Broth (Imedia) and samples were maintained in 20\% (v/v) glycerol solution at $-20{ }^{\circ} \mathrm{C}$ for further use.

\section{Analythical methods}

The biomass estimation was measured via dry weight methodology. Samples were dried in a stove $\left(100{ }^{0} \mathrm{C}\right.$ for $\left.24 \mathrm{~h}\right)$ until constant weight. The Llysine quantification was performed by Chinard method (Chinard 1952), while reducing sugars were determined by Somogyi-Nelson methodology (Miller 1959).

\section{Generation and selection of mutants}

Corynebacterium glutamicum ATCC 21799 was grown on Nutrient agar using the drop plate technique, with six drops per plate. The dishes were then exposed to UV light (lamp of $40 \mathrm{~W}$ ) in complete absence of white light. The time of exposition and the distance to the lamp were optimized in $10 \mathrm{~s}$ and $30 \mathrm{~cm}$, respectively (data not shown). After the period of exposition, the cultures were grown at $30{ }^{\circ} \mathrm{C}$ for $48 \mathrm{~h}$. The surviving colonies were transferred to $120 \mathrm{~mL}$ Erlenmeyers flasks containing $25 \mathrm{~mL}$ of Nutrient broth with addition of $100 \mathrm{mg} / \mathrm{L}$ of thialysine (an analogous of L-Lysine) to select strains resistant to L-Lysine feedback regulation. The media presenting turbidity had the respective cultures maintained in glycerol. The selected cultures were tested for L-Lysine production in a formulated media, and the production of L-Lysine was compared to the parental strain. The best producers were selected for further analysis.

\section{Media formulation and L-Lysine production enhancement}

Initially, the influence of salts and inorganic nitrogen sources $\left(\left(\mathrm{NH}_{4}\right)_{2} \mathrm{SO}_{4},\left(\mathrm{NH}_{4}\right) \mathrm{NO}_{3}\right.$ and urea) on the L-Lysine production by Corynebacterium glutamicum ATCC 21799 was tested in a medium containing $30 \mathrm{~g} / \mathrm{L}$ of glucose. The concentrations of salts and nitrogen sources were initially defined according to literature data (Sassi et al. 1998; Coello et al. 2000; Tada et al. 2001; Ohnishi et al. 2005; Becker et al. 2007), as follow: $1 \mathrm{~g} / \mathrm{L} \mathrm{K}_{2} \mathrm{HPO}_{4}$; $3 \mathrm{~g} / \mathrm{L} \mathrm{KH}_{2} \mathrm{PO}_{4} ; 1 \mathrm{~g} / \mathrm{L} \mathrm{NaCl} ; 0.4 \mathrm{~g} / \mathrm{L} \mathrm{MgSO}_{4} .7 \mathrm{H}_{2} \mathrm{O}$; $10 \mathrm{mg} / \mathrm{L} \mathrm{FeSO}{ }_{4} .7 \mathrm{H}_{2} \mathrm{O} ; 10 \mathrm{mg} / \mathrm{L} \mathrm{MnSO}_{4} .4 \mathrm{H}_{2} \mathrm{O} ; 55$ $\mathrm{mg} / \mathrm{L} \quad \mathrm{CaCl}_{2} .2 \mathrm{H}_{2} \mathrm{O}$. The Corynebacterium glutamicum strain was inoculated into $120-\mathrm{mL}$ Erlenmeyer flasks containing $25 \mathrm{~mL}$ of formulated media at a $5 \%(\mathrm{v} / \mathrm{v})$ inoculation rate. The fermentations were performed at $30{ }^{\circ} \mathrm{C}$ for $72 \mathrm{~h}, \mathrm{pH}$ 7.2 and shaking at $120 \mathrm{rpm}$.

The concentration of glucose was initially set at 40 $\mathrm{g} / \mathrm{L}$ and Nutrient broth at $13 \mathrm{~g} / \mathrm{L}$. Biotin and thiamine were also added at the concentration of $400 \mathrm{ug} / \mathrm{L}$. All the components were autoclaved at $121{ }^{\circ} \mathrm{C}$ by 15 min (carbon and nitrogen sources were autoclaved separately), except biotin and thiamine, which were added to the medium after filtration using $0.22 \mu \mathrm{m}$ membrane filter.

The influence of the salts and vitamins on L-Lysine production was tested using a Plackett-Burmann experimental design (Table 1). After the selection of salts, three inorganic sources of nitrogen were tested $\left(\left(\mathrm{NH}_{4}\right)_{2} \mathrm{SO}_{4}, \quad \mathrm{NH}_{4} \mathrm{NO}_{3}\right.$ and urea). The cultivation conditions and the preparation of materials were the same as cited above. The composition of each tested media was defined as follows: (i) $40 \mathrm{~g} / \mathrm{L}$ of glucose and $13 \mathrm{~g} / \mathrm{L}$ of nutrient broth; (ii) $40 \mathrm{~g} / \mathrm{L}$ of glucose and $10 \mathrm{~g} / \mathrm{L}$ of $\left(\left(\mathrm{NH}_{4}\right)_{2} \mathrm{SO}_{4}\right.$; (iii) $40 \mathrm{~g} / \mathrm{l}$ of glucose and $10 \mathrm{~g} / \mathrm{L}$ of $\mathrm{NH}_{4} \mathrm{NO}_{3}$; (iv) $40 \mathrm{~g} / \mathrm{L}$ of glucose and $10 \mathrm{~g} / \mathrm{L}$ of urea; (v) $40 \mathrm{~g} / \mathrm{l}$ of glucose, $3.3 \mathrm{~g} / \mathrm{L}$ of $\left(\mathrm{NH}_{4}\right)_{2} \mathrm{SO}_{4}, 3.3 \mathrm{~g} / \mathrm{L}$ of $\mathrm{NH}_{4} \mathrm{NO}_{3}$ and $3.3 \mathrm{~g} / \mathrm{L}$ of urea. In the sequence, it was investigated the optimal composition between organic (nutrient broth) and the best inorganic salt, $\left(\mathrm{NH}_{4}\right)_{2} \mathrm{SO}_{4}$, in order to achieved the best L-Lysine production. The culture media was prepared with $80 \mathrm{~g} / \mathrm{L}$ of glucose (optimized concentration, data 
not shown), $20 \mathrm{~g} / \mathrm{L}$ of $\mathrm{CaCO}_{3}$ (added after tests with tamponing agents, data not shown) and salts solution $\left(1 \mathrm{~g} / \mathrm{L} \mathrm{K} \mathrm{K}_{2} \mathrm{HPO}_{4} ; 3 \mathrm{~g} / \mathrm{L} \mathrm{KH}_{2} \mathrm{PO}_{4} ; 0.4 \mathrm{~g} / \mathrm{L}\right.$ $\mathrm{MgSO}_{4} .7 \mathrm{H}_{2} \mathrm{O} ; 10 \mathrm{mg} / \mathrm{L} \quad \mathrm{FeSO}_{4} .7 \mathrm{H}_{2} \mathrm{O} ; 10 \mathrm{mg} / \mathrm{L}$ $\left.\mathrm{MnSO}_{4} .4 \mathrm{H}_{2} \mathrm{O} ; 55 \mathrm{mg} / \mathrm{L} \quad \mathrm{CaCl}_{2} \cdot 2 \mathrm{H}_{2} \mathrm{O}\right)$. The concentrations of nutrient broth and $\left(\mathrm{NH}_{4}\right)_{2} \mathrm{SO}_{4}$ were determined for each assay according to a Central Composite Design Plan (Table 2). The assays were conducted in triplicate for central point and in duplicate for the other levels. Samples were collected at the end of the third day of cultivation.

Table 1 - Plackett-Burmann experimental design - testing the individual effects of salts and vitamins for production of L-Lysine using Corynebacterium glutamicum ATCC 21799

\begin{tabular}{|c|c|c|c|c|c|c|c|c|c|}
\hline Assay & $\begin{array}{c}* \mathrm{~K}_{2} \mathrm{HPO}_{4} \\
+ \\
\mathrm{KH}_{2} \mathrm{PO}_{4}\end{array}$ & $\mathrm{MnSO}_{4} \cdot 4 \mathrm{H}_{2} \mathrm{O}$ & $\mathrm{FeSO}_{4} .7 \mathrm{H}_{2} \mathrm{O}$ & $\mathrm{MgSO}_{4} \cdot 7 \mathrm{H}_{2} \mathrm{O}$ & $\mathrm{NaCl}$ & $\mathrm{CaCl}_{2} \cdot 2 \mathrm{H}_{2} \mathrm{O}$ & Biotin & Thiamine & $\begin{array}{l}\text { L-Lysine } \\
\text { Production } \\
\text { (g/l) }\end{array}$ \\
\hline 1 & 1 & 0 & 1 & 0 & 0 & 0 & 1 & 1 & 1.6 \\
\hline 2 & 1 & 1 & 0 & 1 & 0 & 0 & 0 & 1 & 1.8 \\
\hline 3 & 0 & 1 & 1 & 0 & 1 & 0 & 0 & 0 & 1.4 \\
\hline 4 & 1 & 0 & 1 & 1 & 0 & 1 & 0 & 0 & 1.5 \\
\hline 5 & 1 & 1 & 0 & 1 & 1 & 0 & 1 & 0 & 1.7 \\
\hline 6 & 1 & 1 & 1 & 0 & 1 & 1 & 0 & 1 & 2.5 \\
\hline 7 & 0 & 1 & 1 & 1 & 0 & 1 & 1 & 0 & 2.6 \\
\hline 8 & 0 & 0 & 1 & 1 & 1 & 0 & 1 & 1 & 1.4 \\
\hline 9 & 0 & 0 & 0 & 1 & 1 & 1 & 0 & 1 & 1.1 \\
\hline 10 & 1 & 0 & 0 & 0 & 1 & 1 & 1 & 0 & 1.0 \\
\hline 11 & 0 & 1 & 0 & 0 & 0 & 1 & 1 & 1 & 1.6 \\
\hline 12 & 0 & 0 & 0 & 0 & 0 & 0 & 0 & 0 & 0.7 \\
\hline 13 & 0.5 & 0.5 & 0.5 & 0.5 & 0.5 & 0.5 & 0.5 & 0.5 & 1.9 \\
\hline 14 & 0.5 & 0.5 & 0.5 & 0.5 & 0.5 & 0.5 & 0.5 & 0.5 & 1.8 \\
\hline 15 & 0.5 & 0.5 & 0.5 & 0.5 & 0.5 & 0.5 & 0.5 & 0.5 & 2.2 \\
\hline
\end{tabular}

* Being a pair of salts with known conjugate function, $\mathrm{K}_{2} \mathrm{HPO}_{4}$ and $\mathrm{KH}_{2} \mathrm{PO}_{4}$ were added together. $0=$ absence of the component, $1=$ presence of the component, $0.5=$ presence of the component in half concentration compared to 1 .

Table 2 - Production of L-Lysine by Corynebacterium glutamicum ATCC 21799 for a CCRD testing the levels of organic and inorganic nitrogen sources

\begin{tabular}{cccc}
\hline Nutrient broth $(\mathrm{g} / \mathrm{L})$ & $\left(\mathrm{NH}_{4}\right)_{2} \mathrm{SO}_{4}(\mathrm{~g} / \mathrm{L})$ & L-Lysine $(\mathrm{g} / \mathrm{L})$ & $\begin{array}{c}\text { Standard deviation } \\
(\mathrm{g} / \mathrm{L})\end{array}$ \\
\hline 2.00 & & 5.0 & 0.16 \\
2.00 & 50.0 & 4.1 & 0.95 \\
8.00 & 100.0 & 5.3 & 0.61 \\
8.00 & 50.0 & 2.9 & 0.85 \\
0.76 & 100.0 & 4.9 & 0.55 \\
9.24 & 75.0 & 5.1 & 0.11 \\
5.0 & 75.0 & 5.4 & 0.04 \\
5.0 & 39.6 & 2.8 & 0.30 \\
5.0 & 110.4 & 6.0 & 0.46 \\
\hline
\end{tabular}

Production of L-Lysine in optimized media using bench scale bioreactor with selected mutant strains

In this assay, the carbon source (glucose) was replaced by agroindustrial low value products (sweet potato $(150 \mathrm{~g} / \mathrm{L})$ or sugarcane molasses $(80$ $\mathrm{g} / \mathrm{L})$ ) to produce an L-Lysine rich broth. From the 60 mutant strains, five were chosen for L-Lysine production tests with the defined sugarcane-based medium. The mutant strains were inoculated into120-mL Erlenmeyer flasks containing $25 \mathrm{~mL}$ of formulated media at a $5 \%(\mathrm{v} / \mathrm{v})$ inoculation rate. The fermentations were performed at $30{ }^{\circ} \mathrm{C}$ for 72 h, pH 7.2 and shaking at $120 \mathrm{rpm}$. Finally, the best strain was selected for L-Lysine production in a $5 \mathrm{~L}$ bioreactor (Marubishi - MDL). The cultivation conditions were: agitation of $120 \mathrm{rpm}$ (automatic agitator with 2 flat-blad impellers), temperature of $30^{\circ} \mathrm{C}$, initial $\mathrm{pH}$ of 7.2 and inoculation rate of $5 \%$ $(\mathrm{v} / \mathrm{v})$ and aeration was maintained of $0.75 \mathrm{vvm}$ (filtered atmospheric air - membranes of $0.22 \mu \mathrm{m}$, Milipore).

\section{Preparation of solid matrixes}

Five agroindustrial residues (sugarcane bagasse, citrus pulp, wheat bran, soybean husks and brewers spent grain) were used as solid matrixes to receive the fermented broth rich in L-Lysine. Initially, each 
material was dried in a stove $\left(60{ }^{\circ} \mathrm{C}\right)$ with air circulation for $24 \mathrm{~h}$, then milled in a knife mill and classified. The fractions with 0.8 to $2.0 \mathrm{~mm}$ were selected and maintained under dry conditions until the use.

\section{Production of L-Lysine enriched bran}

The fermented broth enriched in L-Lysine was added to each of the matrixes, until complete saturation. After saturation, the material was dried $\left(100{ }^{\circ} \mathrm{C}\right)$ until constant weight, and then the fermented broth was again added to the solid matrix to restore it. After the $6^{\text {th }}$ cycle, the dried materials was submitted to milling resulting in the L-Lysine enriched bran. All process steps are schematically in Fig. 1.

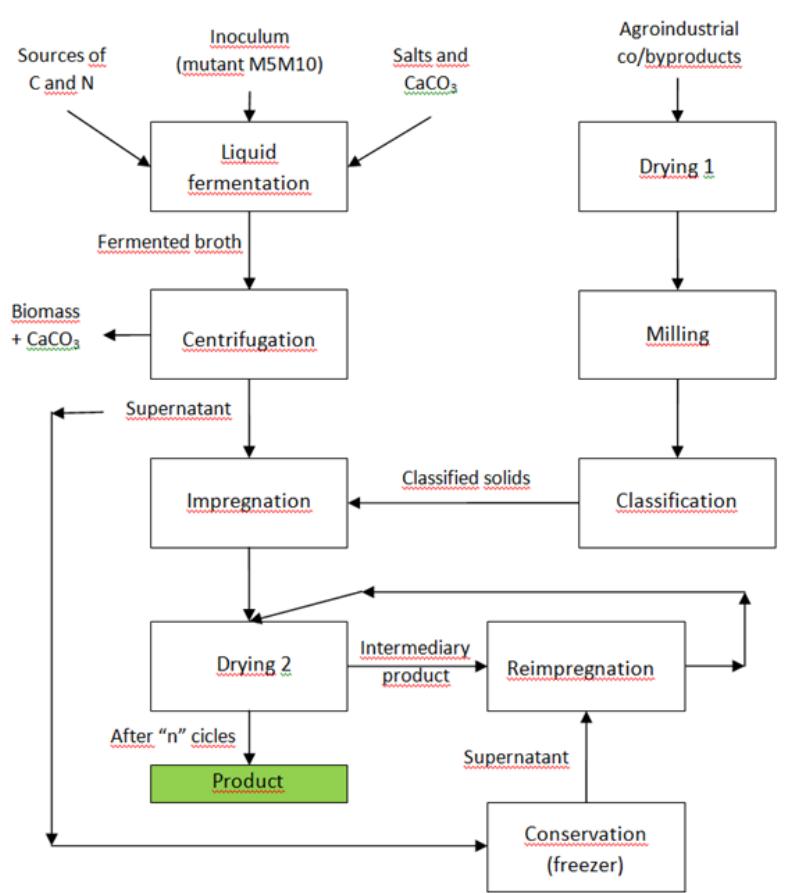

Figure 1 - Schematic view of the proposed process to obtain an enriched L-Lysine bran

\section{RESULTS AND DISCUSSION}

\section{Optimization of L-Lysine production}

Influence of salts and vitamins on Lysine production

The effects of salt and vitamins concentrations on L-Lysine production by Corynebacterium ATCC21799 are shown in Table 1 and Fig. 2. All salts, except $\mathrm{NaCl}$, presented positive influence on L-Lysine production. Manganese and iron salts were certainly the most significant factors on LLysine production (Fig. 2). Thus, for the next steps of this work, all the salts, except $\mathrm{NaCl}$, were maintained. Biotin and thiamine were also removed from the medium formulation due to their low influence for L-Lysine production and high cost. Other studies have demonstrated the specific influence of these salts and vitamins for the production of L-Lysine by submerged fermentation (Sassi 1998; Coello 2000; Tada 2001; Ohnishi 2005; Becker 2007).

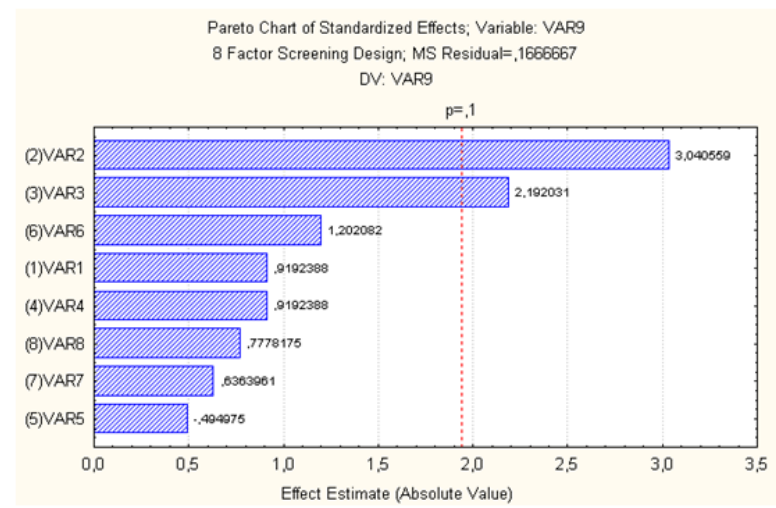

Figure 2 - Pareto Chart showing the individual effect of salts and vitamins over the production of L-Lysine by Corynebacterium glutamicum ATCC 21799. VAR1= K2HPO4+KH2PO4; VAR2= MnSO4.4H20; VAR3= FeSO4.7H20; VAR4= MgSO4.7H20; VAR5= NaCl; VAR6 $=\mathrm{CaCl} 2.2 \mathrm{H} 20 ;$ VAR7 $=$ Tiamine $;$ VAR8=Biotin

Influence of nitrogen sources on biomass and $L$ Lysine production

The biomass and L-Lysine production were studied using different nitrogen sources. The best biomass production was achieved with the medium containing Nutrient broth $(7.1 \mathrm{~h} / \mathrm{L})$, followed by medium containing $\left(\mathrm{NH}_{4}\right)_{2} \mathrm{SO}_{4}(5.9 \mathrm{~g} / \mathrm{L})$; media containing $\left(\mathrm{NH}_{4}\right) \mathrm{NO}_{3}$ and urea as nitrogen sources presented no more than $3.0 \mathrm{~g} / \mathrm{L}$ of biomass (data not shown). Concerning L-Lysine production, only the medium with $\left(\mathrm{NH}_{4}\right)_{2} \mathrm{SO}_{4}$ and Nutrient broth presented significant concentrations of L-Lysine (1.7 g/L and $1.5 \mathrm{~g} / \mathrm{L}$, respectively). Considering these results, $\left(\mathrm{NH}_{4}\right)_{2} \mathrm{SO}_{4}$ was chosen as inorganic nitrogen source for cultivation of the ATCC 21799 strain for subsequent assays, since higher levels of biomass $(5.9 \mathrm{~g} / \mathrm{L})$ and L-Lysine production (1.7 $\mathrm{g} / \mathrm{L})$ were observed when this inorganic nitrogen source was used. The literature data emphasizes the importance of organic nitrogen sources in cultures for bacteria due to the presence of aminoacids, which enables faster assimilation and cell growth (Kind et al. 2013). On the other hand, the costs of organic sources are very high when compared to 
inorganic sources. In this way, the combination of organic and inorganic sources may allow good cell growth with relatively low costs, which was the adopted strategy in the sequence of this work.

Ratio between inorganic and organic nitrogen sources

The influence of different levels of organic and inorganic nitrogen sources on the L-Lysine production by Corynebacterium glutamicum ATCC 21799 was assessed by a CCRD analysis. The factors considered in this assays were Nutrient broth and $\left(\mathrm{NH}_{4}\right)_{2} \mathrm{SO}_{4}$, whose levels are represented in Table 2. The data were submitted to statistical analysis, using the software Statistica 5.0, and the quadratic model with the best adjustment is described by equation 1 :

$Z=5,92-0,067 X-0,37 X^{2}-0,81 Y-$ $0,782 Y^{2}-0,34 X Y$ (Equation 1)

Where:

$\mathrm{OZ}$ is the L-Lysine production

$\circ \mathrm{X}$ is the coded level for nutrient broth

$\circ \mathrm{Y}$ is the coded level for $\left(\mathrm{NH}_{4}\right)_{2} \mathrm{SO}_{4}$

Based on this equation, the resulting theoretical production of L-Lysine (i.e., $\mathrm{Z}$ value) is $6.14 \mathrm{~g} / \mathrm{L}$ in the optimal condition. To validate this result, a test was performed with concentrations of $5.5 \mathrm{~g} / \mathrm{L}$ of Nutrient broth and $61 \mathrm{~g} / \mathrm{L}$ of $\left(\mathrm{NH}_{4}\right)_{2} \mathrm{SO}_{4}$, which resulted in a production of $5.87 \mathrm{~g} / \mathrm{L}$. This result showed a p-value of approximately 0.8 which can be considered satisfactory for the validation of the model, and these values $(5.5 \mathrm{~g} / \mathrm{L}$ of Nutrient broth and $61 \mathrm{~g} / \mathrm{L}$ of $\left.\left(\mathrm{NH}_{4}\right)_{2} \mathrm{SO}_{4}\right)$ were used for further assays.

\section{Generation of mutants}

Development of mutant strains either by using conventional methods or by rDNA technology plays an important role in the enhancement of enzyme yield under the optimized conditions (Nguyen et al. 2012). In the present study, mutation by UV irradiation was used to develop improved strains of Corynebacterium for L-Lysine production. The 19 first generation strains were tested for L-Lysine production capacity. The productions ranged from 0 to $9.4 \mathrm{~g} / \mathrm{L}$ of $\mathrm{L}-\mathrm{L} y s i n e$ (data no shown). This represents an increase of approximately 56\% when compared to the best production of parental strain $(6.0 \mathrm{~g} / \mathrm{L}$ as shown in Table 2). The strain named M5 was selected to further studies (production of $9.4 \mathrm{~g} / \mathrm{L}$ of L-Lysine). The second generation mutants, derived from M5, showed an L-Lysine production of around $10.5 \mathrm{~g} / \mathrm{L}$, namely M5M1, M5M2, M5M10, M5M14 and M5M17 (with production of, respectively, $10.5 \mathrm{~g} / \mathrm{l}$;
$10.6 \mathrm{~g} / \mathrm{L} ; 10.4 \mathrm{~g} / \mathrm{L} ; 10.6 \mathrm{~g} / \mathrm{L}$ and $10.3 \mathrm{~g} / \mathrm{L})$. A third generation of mutants was generated from the five best producers of second generation, but none of them showed better productions than their parental strains (data not shown).

Production of L-Lysine by mutants in formulated media - selection of the best mutant

The five best producers (i.e., M5M1, M5M2, M5M10, M5M14 and M5M17) were selected for production of L-Lysine in a formulated media. Two carbon sources of low cost were selected: sweet potato and sugarcane molasses. The strain M5M10 showed the higher L-Lysine production $(8.9 \mathrm{~g} / \mathrm{L})$ in the medium with sugarcane molasses, being chosen for the final fermentation, aiming to obtain a rich LLysine broth using a low cost substrate. In comparison with the parental strain, which produced $6.9 \mathrm{~g} / \mathrm{L}$ of L-Lysine in the same formulated media, the enhancement was of around $29 \%$.

Production of L-Lysine by mutants in formulated media - selection of ideal concentrations of carbon and nitrogen sources

Some preliminary studies were performed to determine the range of sugarcane molasses and selected nitrogen source $\left(\left(\mathrm{NH}_{4}\right)_{2} \mathrm{SO}_{4}\right)$ in order to establish the levels of this factors for subsequently analyses (data not shown). Thus, a central composite design was used to optimize the concentrations in order to obtain a maxim L-Lysine production in the formulated medium (Table 3). The results demonstrated that the central point (130 $\mathrm{g} / \mathrm{L}$ and $80 \mathrm{~g} / \mathrm{L}$ of sugarcane molasses and ammonium sulfate, respectively) is clearly the ideal condition for maxim production $(9.3 \mathrm{~g} / \mathrm{L})$.

Table 3 - Production of L-Lysine by the mutant M5M10 of Corynebacterium glutamicum ATCC 21799 in media using different concentrations of sugarcane molasses as carbon source and ammonium sulfate as nitrogen source

\begin{tabular}{cccc}
\hline $\begin{array}{c}\text { Coded } \\
\text { levels }\end{array}$ & $\begin{array}{c}\text { Sugarcane } \\
\text { molasses } \\
\text { concentration } \\
(\mathrm{g} / \mathrm{kg})\end{array}$ & $\begin{array}{c}\left(\mathrm{NH}_{4}\right)_{2} \mathrm{SO}_{4} \\
\text { concentration } \\
(\mathrm{g} / \mathrm{kg})\end{array}$ & $\begin{array}{c}\text { L-Lysine } \\
\text { production } \\
(\mathrm{g} / \mathrm{L})\end{array}$ \\
\hline$(-1,-1)$ & 100 & 65 & 6.6 \\
$(-1,1)$ & 100 & 95 & 6.7 \\
$(1,-1)$ & 160 & 65 & 7.2 \\
$(1,1)$ & 160 & 95 & 7.3 \\
$(0,0)$ & 130 & 80 & $\mathbf{9 . 3}$ \\
$(-$ & 87.6 & 80 & 5.2 \\
$\sqrt{2}, 0)$ & & & \\
$(0,-$ & 130 & 58.8 & 5.6 \\
$\sqrt{2})$ & & & \\
$(\sqrt{ } 2,0)$ & 172.4 & 80 & 7.1 \\
\hline
\end{tabular}




\begin{tabular}{llll}
\hline$(0, \sqrt{2})$ & 130 & 101.2 & 7.7 \\
\hline
\end{tabular}

Process for obtaining an L-Lysine enriched bran for animal nutrition

Table 4 shows the amount of L-Lysine in the final material after cycles of impregnation. No L-Lysine was detected in the material previously to the impregnation cycles. The best result was obtained with sugarcane bagasse with a final concentration of L-Lysine of $13.8 \%(\mathrm{~g} / \mathrm{g})$ which represents an increase of approximately $345 \%$ in relation to the product resulting from first cycle. The enriched brans are shown in Fig. 3. According to Rostagno (2011), the demand of aminoacids from animals is variable according to a variety of factors. The most important ones are the species and the phase of growth. Considering the brans generated in the present work (Table 4) and the data for swines (Table 5), it can be calculated the diary demand of ingestion for each bran, shown in Table 6 .

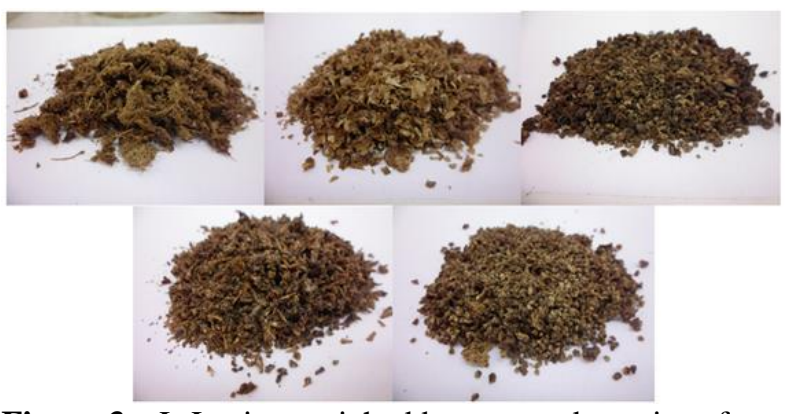

Figure 3 - L-Lysine enriched bran - used matrixes from left top to right bottom: sugarcane bagasse, soybean husk, citrus pulp, brewer spent grain and wheat bran

Table 4 - Relative quantity of L-Lysine in the impregnated material $(\mathrm{g} / \mathrm{g})$ until the sixth cycle of impregnation with fermented broth rich in L-Lysine

$$
\begin{array}{cccccc}
1^{\text {st }} & 2^{\text {nd }} & 3^{\text {rd }} & 4^{\text {th }} & 5^{\text {th }} & 6^{\text {th }} \\
\text { Cycl } & \text { Cycl } & \text { Cycl } & \text { Cycl } & \text { Cycl } & \text { Cycl } \\
\text { e } & \text { e } & \text { e } & \text { e } & \text { e } & \text { e }
\end{array}
$$

\begin{tabular}{llllllll}
\hline $\begin{array}{l}\text { Sugarcan } \\
\text { e bagasse }\end{array}$ & 0.040 & 0.070 & 0.092 & 0.110 & 0.125 & $\mathbf{0 . 1 3 8}$
\end{tabular}

$\begin{array}{ccccccc}\begin{array}{c}\text { Brewer } \\ \text { spent }\end{array} & & & & & & \\ \text { grain } & 0.016 & 0.031 & 0.043 & 0.054 & 0.060 & 0.070\end{array}$

$$
\begin{array}{cllllll}
\text { Citrus } & & & & & & \\
\text { pulp } & 0.021 & 0.039 & 0.054 & 0.067 & 0.079 & 0.089
\end{array}
$$

\section{Wheat

\begin{tabular}{|c|c|c|c|c|}
\hline & \multicolumn{4}{|c|}{ Growth phase } \\
\hline & \multicolumn{3}{|c|}{ Pre Initial } & \multirow[t]{2}{*}{ Initial } \\
\hline & 1 & 2 & 3 & \\
\hline Live weight & 3.5 to & 5.5 to & 9.3 to & 15 to \\
\hline$(\mathrm{kg})$ & 5.3 & 9.0 & 15 & 30 \\
\hline \multirow[t]{2}{*}{ Age (days) } & 14 to & 21 to & 33 to & 41 to \\
\hline & 21 & 32 & 42 & 70 \\
\hline $\begin{array}{c}\text { Rough } \\
\text { protein }(\%)\end{array}$ & 20.0 & 20.0 & 21.0 & 19.24 \\
\hline $\begin{array}{l}\text { Digestible } \\
\text { L-Lysine } \\
(\%)\end{array}$ & 1.520 & 1.450 & 1.330 & 1.093 \\
\hline $\begin{array}{l}\text { *DWG } \\
(\mathrm{kg} / \mathrm{dia})\end{array}$ & 0.257 & 0.318 & 0.633 & 1.265 \\
\hline
\end{tabular} \\ $\begin{array}{lllllll}\text { bran } & 0.013 & 0.025 & 0.035 & 0.045 & 0.052 & 0.059\end{array}$ \\ $\begin{array}{ccccccc}\begin{array}{c}\text { Soybean } \\ \text { husk }\end{array} & 0.020 & 0.036 & 0.051 & 0.063 & 0.074 & 0.084\end{array}$}

Table 5 - Demand for proteins and aminoacids for swine, according to the growth phase

Table 6 - Demand of each product (bran) per day, per swine, according to the growth phase

\begin{tabular}{cccccc}
\hline & \multicolumn{5}{c}{ Product (bran) (g/day.swine) } \\
\cline { 2 - 6 } & $\begin{array}{c}\text { Sugarca } \\
\text { ne } \\
\text { bagasse }\end{array}$ & $\begin{array}{c}\text { Brewe } \\
\mathrm{r} \\
\text { spent } \\
\text { grain }\end{array}$ & $\begin{array}{c}\text { Citru } \\
\text { s } \\
\text { pulp }\end{array}$ & $\begin{array}{c}\text { Whe } \\
\text { at } \\
\text { bran }\end{array}$ & $\begin{array}{c}\text { Soybea } \\
\text { n husk }\end{array}$ \\
\hline $\begin{array}{c}\text { Pre- } \\
\text { initia } \\
11\end{array}$ & 5.7 & 11.2 & 8.8 & 13.2 & 9.3 \\
$\begin{array}{c}\text { Pre- } \\
\text { initia } \\
12\end{array}$ & 6.7 & 13.2 & 10.4 & 15.6 & 11.0 \\
$\begin{array}{c}\text { Pre- } \\
\text { initia } \\
13\end{array}$ & 12.8 & 25.3 & 19.9 & 30.0 & 21.0 \\
$\begin{array}{c}\text { Initia } \\
1\end{array}$ & 19.3 & 38.0 & 29.9 & 45.1 & 31.7 \\
\hline
\end{tabular}

Considering the period of higher demand (initial phase of growth for swines) the necessities are: (i) $19.3 \mathrm{~g}$ of bran from sugarcane bagasse per day per swine; (ii) $38.0 \mathrm{~g}$ of bran from brewer spent grain per day per swine; (iii) $29.9 \mathrm{~g}$ of bran from citrus pulp per day per swine; (iv) $45.1 \mathrm{~g}$ of bran from wheat per day per swine; and (v) $31.7 \mathrm{~g}$ of bran from soybean husk per day per swine. Therefore, the mensal demand for each product (for swine in initial phase of growth) would be of $578 \mathrm{~g}$ 
sugarcane bagasse; $1140 \mathrm{~g}$ brewer spent grain; 897 $\mathrm{g}$ citrus pulp; $1353 \mathrm{~g}$ wheat bran; and $950 \mathrm{~g}$ soybean husk. Considering an average cost of the raw materials: amonium sulphate (U\$ $1.40 / \mathrm{kg}$ ); sugarcane molasses (U\$ 0.20/kg); calcium carbonate (U\$ 0.60/kg); and the quantities required for the 6 cycles of impregnation for each bran (Letti, 2014), it is possible to estimate the cost for each $\mathrm{kg}$ of processed bran: sugarcane bagasse (U\$ 1.44); brewer spent grain (U\$ 1.00); citrus pulp (U\$ 1.22); wheat bran (U\$ 0.98); and soybean husk (U\$ 1.08). The cost of the solid matrixes was negligible, since they are non considerable when compared to the other raw materials costs.

Finally, the estimation for cost of each processed bran (Fig. 3) to supply the monthly demand for 1 swine in the initial phase of growth is as follows: sugarcane bagasse (U\$ 0.83); brewer spent grain (U\$ 1.13); citrus pulp (U\$ 1.10); wheat bran (U\$ 1.32) and soybean husk (U\$ 1.03). The average price for L-Lysine crystals usually found in the market is around U\$ $2.25 / \mathrm{kg}$ (Harte 2013).

Considering the average production of L-Lysine in competitive industrial plants is around $80 \mathrm{~g} / \mathrm{L}$ (Tada 2001), and the market price of L-Lysine crystals around U\$2.25/kg, the average cost to feed 1 swine in initial phase of growth would be of U\$ 0.45. In this work, the production of L-Lysine obtained via submerged fermentation was $9.3 \mathrm{~g} / \mathrm{L}$ and, therefore, the final prizes of the processed bran are still not competitive. However, if it is considered a liquid fermentation with yield of $80 \mathrm{~g} / \mathrm{L}$ of L-Lysine, and the same processing steps, the costs would be reduced to U\$ 0.10; U\$ 0.13; U\$ 0.13; U\$ 0.15 and U\$ 0.12 , for processed bran based on sugarcane bagasse, brewer spent grain, citrus pulp, wheat bran and soybean husk, respectively, turning, this way, the final prices competitive (specially the product based on sugarcane bagasse). In summary, the potential presented in this work is considerable, based in a possible enhancement of the yield of LLysine in the submerged fermentation step.

\section{CONCLUSIONS}

In the present work, the potential production of LLysine with the strain Corynebacterium glutamicum ATCC 21799 was enhanced from around $1.0 \mathrm{~g} / \mathrm{L}$ to $9.3 \mathrm{~g} / \mathrm{L}$. Media composition optimization of salts, organic and inorganic nitrogen sources and agroindustrial byproducts as carbon sources were partially responsible for these results, besides the generation and selection of UV mutant strains. It was also proposed a process for obtaining of products to be used as animal feed. The L-Lysine enriched bran obtained using the fermentation broth and solid agroindustrial matrixes shows an interesting market potential, mainly if the L-Lysine production in the submerged fermentation step is further enhanced.

\section{ACKNOWLEDGMENTS}

The authors wish to thank the Brazilian agencies Conselho Nacional de Desenvolvimento Científico e Tecnológico (CNPQ) for financial support and scholarships.

\section{REFERENCES}

Anastassiadis S. L-lysine fermentation. Recent Patents on Biotechnology. 2007; 1:11-24.

Becker J, Klopprogge C, Herold A, Zelder O, Bolten CJ, Wittmann C. Metabolic flux engineering of 1-lysine production in Corynebacterium glutamicum - over expression and modification of G6P dehydrogenase. J Biotechnol. 2007; 132:99-109.

Chinard F. Photometric Estimation of Proline and Ornithine. J Biol Chem. 1952.

Coello N, Brito L, Nonus M. Biosynthesis of L-lysine by Corynebacterium glutamicum grown on fish silage. Bioresource Technol. 2000; 73: 221-225.

Coello N, Montiel E, Concepcion M, Christen P. Optimization of a Culture Medium Containing Fish Silage for L-Lysine Production by Corynebacterium glutamicum. Bioresource Technol. 2002; 85:207-21.

Eggeling L, Bott M. A giant market and a powerful metabolism: L-lysine provided by Corynebacterium glutamicum. Appl Microbiol Biotechnol. 2015; 99(8):3387-3394.

Kelle R, Hermann T, Bathe B. L-Lysine Production. In: Eggeling L, Bott M, Editors. Handbook of Corynebacterium glutamicum. Boca Raton: CRC Press; 2005. $465-488$.

Kind S, Becker J, Wittmann C. Increased lysine production by flux coupling of the tricarboxylic acid cycleand the lysine biosynthetic pathwayMetabolic engineering of the availability of succinylCoA in Corynebacterium glutamicum. Metab Eng. 2013; 15:184-195.

Letti, LAJ. Produção de L-Lisina por Processos Fementativos e Desenvolvimento de Produto para Nutrição Animal. Doctor Thesis - Bioprocess Engineering, Federal University of Paraná, Curitiba, Brazil, 2014. 
Miller GL. Use of dinitrosalicylic Acid Reagent for Determination of Reducing Sugars. J Anal Chem. 1959; 3:426-428.

Nguyen HL, Nguyen SC, Do Van G, Nguyen TQH, Hoang TQ, Nguyen DH. Production of recombinant NPRC10 protease in 14-L fermentation scale. Eur $J$ Exp Biol. 2012; 4:913-918.

Odunfa SA, Adeniran SA, Teniola OD, Nordstrom J. Evaluation of lysine and methionine production in some lactobacilli and yeast from Ogi. Int J Food Microbiol. 2001; 63:159-163.

Ohnishi J, Katahira R, Mitsuhashi S, Kakita S, Ikeda M. A novel gnd mutation leading to increased L-lysine production in Corynebacterium glutamicum. FEMS Microbiol Lett. 2005; 242:265-274.

Rostagno, H. S. Tablas brasileñas para aves y cerdos. Universidade Federal de Viçosa, Departamento de Zootecnia (2011).
Sassi AH, Fauvart L, Deschamps AM, Lebeault JM. Fedbatch production of L-lysine by Corynebacterium glutamicum. Biochem Eng J. 1998; 1:85-90.

Shah AH, Hameed A, Khan GM. Fermentative Production of L-lysine: bacterial fermentation I. $J$. Med. Sci. 2002; 2:152-157.

Tada K, Kishimoto M, Omasa T, Katakura Y, Suga KI. Constrained optimization of L-lysine production based on metabolic flux using a mathematical programming method. J Biosci Bioeng. 2001; 4:344351.

Wittmann C, Becker J. The L-Lysine Story: From Methabolic Pathways to Industrial Production. Microbiol Monogr. 2007; 5:40-62.

Received: December 21, 2015; Accepted: March 02, 2016. 